\title{
The impact of different shift work schedules on the levels of anxiety and stress in workers in a petrochemicals company
}

\author{
O impacto dos diferentes esquemas de trabalhos em turnos \\ nos níveis de ansiedade e de stress dos trabalhadores \\ de uma empresa petroquímica
}

\author{
Katie Moraes de ALMONDES \\ John Fontenele ARAÚJO²
}

\begin{abstract}
This study evaluated anxiety and stress in workers under different shift work conditions. The sample comprised 239 workers, with an average age of 42.6 , standard deviation $=5.7$ years, divided into fixed daytime working $(n=52)$ and different working shifts ( $n=187$ ). Documentation: Free and informed consent form; ID's; State-Trait Anxiety Inventory; Lipp's Stress Symptom Inventory for Adults. We used the $t$-test for independent samples, ANOVA, Pearson's correlation and the two-sample Comparison of proportions Test. Results showed that shift workers had higher State-Trait Anxiety scores than fixed daytime workers ( $t=-4.994 ; p=0.0001$; $t=-2.816 ; p=0.005$, respectively). Both samples exhibited stress, but there were no statistically significant differences between the groups ( $t=-1.052 ; p=0.294)$. Shift work schedules caused more situational and dispositional anxiety, but did not significantly increase stress levels when compared to fixed daytime working.
\end{abstract}

Uniterms: Anxiety. Emotional states. Stress. Personnel. Shift work.

\section{Resumo}

Este trabalho avaliou ansiedadee estresse em trabalhadores em diferentes esquemas de trabalhos. Participaram 239 trabalhadores, idade média 42,6, desvio-padrão = 5,7 anos, divididos em trabalho diurno fixo ( $n=52)$ e diferentes trabalhos em turno ( $n=187)$. Protocolos: Termo de Consentimento Livree Esclarecido, Ficha de Identificação, Inventário de Ansiedade Traço-Estado, Inventário de Sintomas de Stress para Adultos de Lipp. Foram utilizados teste t para amostras independentes, ANOVA, teste de correlação de Pearson e teste de Comparação de Proporções. Os resultados mostraram que os trabalhadores em turnos apresentaram maiores escores de Ansiedade Traço-Estado quando comparados com os trabalhadores diurnos fixos ( $t=-4,994, p=0,0001 ; t=-2,816, p=0,005$, respectivamente). As duas amostras apresentaram stress, mas não houve diferenças estatisticamente significativas entre os grupos ( $t=-1,052 ; p=0,294)$. Esquemas de trabalhos em turnos causam mais ansiedade situacional e disposicional, mas não elevam significativamente níveis de stress quando comparados com diurnos fixos.

Unitermos: Ansiedade. Estado emocionais. Stress. Recursos humanos. Trabalho por turno.

1 Faculdade Natalense para o Desenvolvimento do Rio Grande do Norte, Departamento de Psicologia. R. Pref. Eliane Barros, 2000, Tirol, 59014-540, Natal, RN, Brasil. Correspondência para/Correspondence to: K.M. ALMONDES. E-mail:<kmalmondes@ufrnet.br>.

2 Universidade Federal do Rio Grande do Norte, Departamento de Psicologia. Natal, RN, Brasil. 
The incidence of stress and anxiety disorders in industrial cities has increased significantly, causing negative impacts on the economy and on the quality of life, such as work interruptions and the risk of suicide (Kalia, 2002). This has led some researchers to call the XX century the "Age of Anxiety" (Lecrubier, 2001; Twenge, 2000).

There is evidence that temporal organization in the shift work schedules of companies/industries is one of the factors that raises stress and anxiety levels by negatively affecting physical and mental health and human performance (Monk, 1988; Olsson, Kandolin \& Kauppinen-Toropainen, 1989). This occurs because temporal organization in work schedules at non-usual times forces individuals to successive physiological and behavioral adaptations because of: 1) the broken phase relations between the organism and the work hours and the broken relation between the phases of the different endogenous rhythms (circadian alterations); 2) shortened, irregular or fragmented sleep (homeostatic alterations) and 3) absence of family life because of the work schedule, loss of relationships, and social activities, among others (psychosocial alterations) (Costa, 1996; Harrington, 1994; Monk, 2000).

All these alterations and their consequences (gastrointestinal diseases, chronic fatigue, mood alterations, cardiovascular disorders, hypertension, etc. (Andalauer, Prin, Malbec, Vieux \& Bourdeleau, 1984; Monk, 2000; Reinberg et al., 2001) are partly a result of the schedules and demands of work, which may be interpreted by individuals as threatening factors that generate conflict and thus provoke stress and anxiety responses.

Previous studies demonstrate that alterations in circadian, homeostatic and psychosocial mechanisms lead to a stress response. Van Carter and Spiegel (2000) showed that in a situation of sleep deprivation (homeostatic alteration) or of irregular sleep-wake cycle (circadian alteration), there is an increased response in the oral glucose tolerance test, elevated plasma cortisol concentration in the evening and increased sympathetic activity. These responses are similar to those provoked by a situation of chronic stress. Furthermore, they contribute to the development of chronic diseases such as obesity, diabetes and hypertension. Smith and Folkard (1993) observed an association between shift work and symptoms of stress and anxiety in family and social life. They showed that even the wives of workers in continuous shifts complained of stress, since they were often alone, had more responsibility for the children, ate at irregular hours and were concerned about noise interfering in their husband's sleep. Workers, on the other hand, complained of tiredness related to sleep deprivation and stress linked to social and family life. Barton, Aldridge and Smith (1998) showed that children of night shift workers also experienced stress because of their father's work.

Williams, Magid and Steptoe (2005) demonstrated that workers under a scheme of alternating 8-hrs daytime shifts starting at 5 hrs had high cortisol levels on waking, seemingly associated with chronic stress. However, workers under the same scheme starting at 8hrs had normal cortisol levels. The magnitude of cortisol responses on waking is likely associated to the interruption of sleep at a very early hour, leading to poor sleep quality and a break in the diurnal cortisol cycle (homeostatic and circadian alterations).

Even though these studies show the association between circadian, homeostatic and psychosocial alterations and stress/anxiety, the literature is lacking or divergent in demonstrating a direct relationship between anxiety and stress levels and identifying which shift work schedules are the most harmful. Piko (1999), Krivoschecov, Sobakin and Fomin (2003), Portela, Rotenberg and Waissmann (2004), Williams et al. (2005) and Choobineh, Rajaeefard and Neghab (2006), showed that alternating $12 \mathrm{hrs}$ shift schedules, both night and day, are related to high stress and anxiety levels. Other studies indicate that night shift work in particular causes more stress and anxiety (Costa, 2004; Ruggiero, 2003). McVicar (2003) found more anxiety in $12 \mathrm{hrs}$ shifts than in 8hrs shifts. However, there are no data in the literature comparing the relation between stress and anxiety between different work schedules.

Comparative studies between work schedules and health problems in petrochemical companies are scarce, but their results do not diverge with those of for other industries. Greater health and sleep problems are found in 12 hrs shifts than in fixed work schedules (Bourdouxhe, Quéinnec, Granger, Baril, Guertin \& Massicotte, 1999; Fischer, Moreno, Borges \& Louzada, 2000) and in 8hrs shifts when compared with $12 \mathrm{hrs} \mathrm{shifts}$ 
(Lowden, Kecklund, Axelsson \& Akerstedt, 1998; Tucker, Barton \& Folkard, 1996). There are few studies on the relationship between anxiety/stress levels and shift work in petrochemical companies.

In a previous study (Almondes \& Araújo, 2007) the lifestyle and activities of workers in varied work schedules in a petrochemical company were studied using a scale Social Rhythms Metric (SRM). The SRM enables us to quantify the circadian rhythm amplitude in the behavioral domain and the individuals' entrainment to the environment in at 24-hour period, during their rest and work days. The results showed daytime worker and shift worker groups had daily lifestyle irregularity and no statistically significant correlations were found between sleep quality, demographic characteristics, social data and shift work.

Accordingly, the aim of this study was to assess the subjective anxiety and stress of workers in a petrochemical company on a fixed daytime shift and on three different work shift schedules (rotating shift, faster day shift, slower day shift).

\section{Method}

\section{Subjects}

A total of 239 workers from a Brazilian petrochemical company took part in the study. All the subjects were men between 22 and 55 years of age (Mean age- $M=42.56$, standard deviation $-d p=5.66$ ).

The participants were divided according to their work schedule with different environmental characteristics as follows:

1) Fixed daytime work group ( $n=52)$ : these employees worked only during the daytime and kept the same work schedule (from 8 am to $5 \mathrm{pm}$ ); lived in the same city as their workplace and performed administrative tasks.

2) Shift worker group ( $n=187$ ): these employees had a rotating work schedule, and were divided as follows:

- Rotating shift group ( $n=66$ ): these employees worked on rotating day and night shifts $12 \mathrm{hrs}$ ( 7 day shifts, 7 rest days, 7 night shifts and 14 rest days) from 7am to $7 \mathrm{pm}$ and after a 7 -day rest, worked from $7 \mathrm{pm}$ to 7am; worked onshore for a petroleum company involved in extraction, refining and process monitoring; worked in a different city from that in which they lived; slept in lodgings or in trailers at the work site;

- Slower day shift group ( $n=14)$ : these employees worked only rotating day shifts $12 \mathrm{hrs}$ (7 day shifts, 7 rest days, 7 day shifts and 14 rest days) from 6am to 6pm; worked offshore for a petroleum company; slept in lodgings at the work site;

- Faster day shift group ( $n=107$ ): these employees worked only rotating day shifts 9.5 hrs (4 day shifts, 3 rest days) from 7am to 5:45pm; worked onshore in different cities from those in which they lived; some workers in this group ( $n=76$ ) worked $100 \mathrm{~km}$ from company headquarters and slept in neighboring cities or in lodgings near the work site; others $(n=31)$ worked at headquarters and slept in lodgings at their work site.

Protocols and Procedures: data collection was conducted at a petrochemical plant in various sectors with different characteristics, functions and work schedules. Each sector was visited, and the study was explained to the potential volunteers. In the onshore and offshore sections orientation was given in the work place at lunch time or at a meeting with all the workers; before in the middle or at the end of the shift. The research was conducted from January through June 2006. Since the work force of this company is predominantly composed of men, there were no sex or age criteria. The workers' mental health assessment was performed in collaboration with the company's health service, and those with possible psychiatric disorders were excluded. The volunteers were divided according to their work schedules, gave their written informed consent and filled out an identification form containing questions about personal information, work scheme and health problems. They then completed:

1) State-Trait Anxiety Inventory (STAI), containing 20 statements aimed at measuring anxiety traits. This instrument is used to choose individuals whose tendency to react to psychological pressure of different intensities varies and to measure the state of anxiety in order to determine the real intensity levels of the anxiety state (Spielberg, Gorsuch \& Lushene, 1979).

2) Lipp's Stress Symptom Inventory (LSSI), which aims at evaluating if the individual has symptoms of 
stress, the type of symptom (somatic or psychosomatic) and the stress phase in which the individuals find themselves (alert phase where the organism prepares for fight or flight; resistance phase - constant stress to which the individual tries to adapt exhaustion phase - the stressor is constant and the quasi - exhaustion and individuals have no strategies to deal with it; the organism exhausts its adaptive energy reserve and more serious diseases appear) (Lipp, 2000).

All the procedures and protocols were approved by the Ethics Committee of the Universidade Federal do Rio Grande do Norte. We used the t-test for independent samples, ANOVA with post hoc test for multiple comparisons and Pearson's correlation test with simple regression analysis, in addition to the two-sample comparison of proportions test.

\section{Results}

The demographic characteristics of 239 workers under different shift systems show that they are similar in age ( $F=0.376 ; p=0.770$; and Mann-Whitney for slower $p>0.98)$, schooling level $(Z=6.74 ; p=0.76)$, number of children ( $F=2.514, p=0.85$; Mann-Whitney $p=0.195)$, marital status $(Z=8.79 ; p=0.08)$. The only difference found was with extra-work activities (studies, volunteer work, etc.) for the slower day shift group, which differed from the other groups ( $Z=2.35 ; p=0.04$ ), since $85.7 \%$ performed no extra-work activities on their days off (Table 1 ).

The mean state-trait anxiety of the 239 workers (general sample) was media - $\mathrm{M}=36.2, \mathrm{SD}=8.64$ and $M=36.5, S D=7.47$, respectively (Table 2). he data showed that $16.3 \%$ of the workers exhibited stress. The LSSI identifies which stress phase the individual is in and which symptom is most prevalent. The resistance phase was diagnosed (the individual displays stress and is trying to deal with the stressors in order to maintain internal homeostasis), with predominantly psychological symptoms.

A comparative analysis of mean state anxiety scores between the fixed daytime workers and shift workers showed that the former had lower mean state anxiety scores $\mathrm{M}=31.10, \mathrm{SD}=6.35$ versus $\mathrm{M}=37.54, \mathrm{SD}=8.67$; $t=-4.994 ; p=0.0001)$, and lower mean trait anxiety scores

Table 1. Demographic characteristics of petrochemical workers under different shift schedules (n=239). 2006.

\begin{tabular}{|c|c|c|c|c|c|c|c|c|c|c|c|c|}
\hline \multirow[t]{2}{*}{ Variables } & \multicolumn{2}{|c|}{$\begin{array}{l}\text { General sample } \\
\qquad(n=239)\end{array}$} & \multicolumn{2}{|c|}{$\begin{array}{l}\text { Daytime worker } \\
\text { group }(\mathrm{n}=52)\end{array}$} & \multicolumn{2}{|c|}{$\begin{array}{l}\text { Shift Workers } \\
\qquad(\mathrm{n}=187)\end{array}$} & \multicolumn{2}{|c|}{$\begin{array}{l}\text { Rotating shift } \\
\text { group }(n=66)\end{array}$} & \multicolumn{2}{|c|}{$\begin{array}{l}\text { Slower day shift } \\
\text { group }(n=14)\end{array}$} & \multicolumn{2}{|c|}{$\begin{array}{l}\text { Faster day shift } \\
\text { group }(n=107)\end{array}$} \\
\hline & $M$ & SD & $M$ & SD & $M$ & SD & $M$ & SD & $M$ & SD & $M$ & SD \\
\hline Age & 42.56 & 5.7 & 42.33 & 7.8 & 42.5 & 5.34 & 42.9 & 5.0 & 41.6 & 5.0 & 42.4 & 5.5 \\
\hline \multirow[t]{2}{*}{ Children } & 2.4 & 1.1 & 2.0 & 1.5 & 2.5 & 1.0 & 2.5 & 1.0 & 2.3 & 1.0 & 2.5 & 1.1 \\
\hline & $n$ & $\%$ & $n$ & $\%$ & $n$ & $\%$ & $n$ & $\%$ & $n$ & $\%$ & $\mathrm{n}$ & $\%$ \\
\hline Schooling level & 13 & 5.4 & 2 & 3.8 & 11 & 5.9 & 3 & 4.6 & 1 & 7.1 & 7 & 6.5 \\
\hline Elementary & 102 & 42.7 & 13 & 25 & 89 & 47.6 & 30 & 45.5 & 11 & 78.6 & 48 & 45.0 \\
\hline Secondary & 95 & 39.7 & 33 & 63.5 & 62 & 33.2 & 18 & 27.3 & 2 & 14.3 & 42 & 39.3 \\
\hline University & 29 & 12.13 & 4 & 7.7 & 25 & 13.4 & 15 & 22.7 & 1 & 7.1 & 10 & 9.3 \\
\hline Others & & & & & & & & & & & & \\
\hline Marital state & 199 & 83.3 & 40 & 77.0 & 158 & 84.5 & 55 & 83.33 & 11 & 78.6 & 92 & 86 \\
\hline Married & 23 & 9.6 & 8 & 15.4 & 15 & 8.0 & 7 & 10.6 & 1 & 7.1 & 7 & 6.5 \\
\hline Single & 14 & 5.9 & 3 & 5.8 & 11 & 5.9 & 2 & 3 & 2 & 14.3 & 7 & 6.5 \\
\hline Divorced & 2 & 0.84 & - & & 2 & 1.1 & 2 & 3 & - & & - & \\
\hline 2 or more & & & & & & & & & & & & \\
\hline $\begin{array}{l}\text { consensual unions } \\
\text { Others }\end{array}$ & 1 & 0.41 & 1 & 1.9 & 1 & 0.53 & & & - & & 1 & 0.9 \\
\hline Extra-work activities & 72 & 30 & 17 & 32.7 & 53 & 28.3 & 19 & 28.8 & 1 & 7.14 & 33 & 30.8 \\
\hline Physical activity & 38 & 15.9 & 9 & 17.3 & 29 & 15.5 & 10 & 15.2 & 1 & 7.14 & 18 & 16.8 \\
\hline Study & 25 & 10.5 & 3 & 5.8 & 14 & 7.5 & 5 & 7.6 & - & & 9 & 8.4 \\
\hline Other employment & 3 & 1.3 & 2 & 3.9 & 1 & 0.5 & 1 & 1.5 & & & - & \\
\hline $\begin{array}{l}\text { Volunteer work } \\
\text { None }\end{array}$ & 101 & 42.3 & 21.0 & 40.4 & 90 & 48.0 & 31.0 & 47.0 & 12.0 & 85.7 & 47.0 & 43.9 \\
\hline
\end{tabular}

SD: standard deviation; M: Mean age. 
$M=33.88, S D=7.03$ versus $M=37.14, S D=7.46 ; t=2.816$; $p=0.005)$. These data suggest that shift workers were and are more anxious (state and trait) (Table 2).

As for stress, $11.54 \%$ of the sample of fixed daytime workers had stress with psychological symptoms in the resistance phase, whereas $18.7 \%$ of the shift workers exhibited stress in the resistance phase, $4.3 \%$ with physical symptoms and $14.4 \%$ with psychological symptoms (Table 2), suggesting that the shift workers are more stressed. However, a comparative analysis of stress scores between the two groups did not confirm this supposition ( $t=-1.052 ; p=0.294$ ) (Table 2 ).

Comparative analysis of mean state anxiety scores between the subgroups of shift workers $M=36.20$, $S D=8.21$ for the rotating shift group, $M=41.36, S D=9.25$ for the slower day shift group and $M=37.87, S D=8.78$ for the faster day shift group), showed no statistically significant differences between the groups ( $F=2.253$; $p=0.108$ ). However, we found a difference in mean trait anxiety scores among the three shift groups $M=35.61$, $S D=5.97$ for the rotating shift, $M=41.07, S D=5.97$ for the slower day shift, and $\mathrm{M}=37.57, \mathrm{SD}=7.85$ for the faster day shift). The slower day shift group had higher trait anxiety scores than those of the rotating shift group ( $F=3.614$; $p=0.03$ ), suggesting that the slower group is anxious (Tables 2 and 3).

In the test comparing mean state anxiety scores between the fixed daytime workers and the different shift workers, we found that the former had lower situational anxiety scores, suggesting that all the shift worker subgroups were more anxious ( $F=10.086$; $p=0.001$ ) (Table 3). The slower day shift and faster day shift workers had higher dispositional anxiety than the fixed daytime workers, suggesting that these two shift worker subgroups were more anxious ( $F=5.158 ; p=0.02$ ) (Table 3).

Analysis of the stress results for the shift workers showed that $23.0 \%$ of the rotating shift, $36.0 \%$ of the slower day shift and $12.2 \%$ of the faster day shift group had stress in the resistance phase. We found a predominance of psychological stress symptoms (Table 2). No statistically significant differences in stress data were observed among the shift worker subgroups $(F=3.335 ; p=0.173)$.

Table 2. Mean state-trait anxiety scores of petrochemical workers under different work schedules. 2006.

\begin{tabular}{|c|c|c|c|c|c|c|c|c|c|c|c|c|}
\hline \multirow[t]{2}{*}{ Variables } & \multicolumn{2}{|c|}{$\begin{array}{l}\text { General sample } \\
\qquad(n=239)\end{array}$} & \multicolumn{2}{|c|}{$\begin{array}{l}\text { Daytime worker } \\
\text { group }(n=52)\end{array}$} & \multicolumn{2}{|c|}{$\begin{array}{l}\text { Shift Workers } \\
\qquad(n=187)\end{array}$} & \multicolumn{2}{|c|}{$\begin{array}{l}\text { Rotating shift } \\
\text { group }(n=66)\end{array}$} & \multicolumn{2}{|c|}{$\begin{array}{l}\text { Slower day shift } \\
\text { group }(n=14)\end{array}$} & \multicolumn{2}{|c|}{$\begin{array}{l}\text { Faster day shift } \\
\text { group }(n=107)\end{array}$} \\
\hline & $M$ & SD & $M$ & SD & $M$ & SD & $M$ & SD & $M$ & SD & $M$ & SD \\
\hline State anxiety & 36.2 & 8.64 & 31.10 & $6.35^{\mathrm{a}}$ & 37.54 & $8.67^{a}$ & 36.20 & 8.21 & 41.36 & 9.25 & 37.87 & 8.78 \\
\hline Trait anxiety & 36.5 & 7.47 & 33.88 & $7.03^{b}$ & 37.14 & $7.46^{\mathbf{b}}$ & 35.61 & 5.97 & 41.07 & 5.97 & 37.57 & 7.85 \\
\hline Stress \% & \multicolumn{2}{|c|}{16.3} & \multicolumn{2}{|c|}{11.54} & \multicolumn{2}{|c|}{18.7} & \multicolumn{2}{|c|}{23.2} & \multicolumn{2}{|c|}{36} & \multicolumn{2}{|c|}{12.2} \\
\hline Stress symptoms & \multicolumn{2}{|c|}{$\begin{array}{l}\text { psychological } \\
\text { and } 10.3 \text { physical }\end{array}$} & \multicolumn{2}{|c|}{ psychological } & $\begin{array}{l}4.3 \text { phy } \\
\text { psych }\end{array}$ & $\begin{array}{l}\text { cal and } \\
4 \\
\text { ogical }\end{array}$ & 6 phy & $\begin{array}{l}\text { al and } \\
2 \\
\text { ogical }\end{array}$ & \multicolumn{2}{|c|}{$\begin{array}{l}\text { physical and } \\
\text { psychological }\end{array}$} & \multicolumn{2}{|c|}{ psychological } \\
\hline Stress phase & \multicolumn{2}{|c|}{ Resistance } & \multicolumn{2}{|c|}{ Resistance } & \multicolumn{2}{|c|}{ Resistance } & \multicolumn{2}{|c|}{ Resistance } & \multicolumn{2}{|c|}{ Resistance } & \multicolumn{2}{|c|}{ Resistance } \\
\hline
\end{tabular}

a) Statistically significant differences between the fixed daytime group and shift workers ( $t$-test; $t=4.994 . p=0.0001$ );

b) Statistically significant differences between the fixed daytime group and shift workers $(t$-test; $t=-2.816, p=0.005)$.

Table 3. Comparison of mean state-trait anxiety scores and stress data of workers under different work schedules (ANOVA; $p<0.05$ ). 2006.

\begin{tabular}{|c|c|c|c|c|c|c|}
\hline & \multicolumn{2}{|c|}{ State } & \multicolumn{2}{|c|}{ Trait } & \multicolumn{2}{|c|}{ Stress } \\
\hline & $\mathrm{F}$ & $P$ & F & $P$ & $\mathrm{~F}$ & $P$ \\
\hline Fixed daytime work group * Rotating shift group & 10.086 & 0.04 & 5.158 & NS & 2.739 & NS \\
\hline Fixed daytime work group * Faster day shift group & 10.086 & 0.001 & 5.158 & 0.01 & 2.739 & NS \\
\hline Fixed daytime work group * Slower day shift group & 10.086 & 0.001 & 5.158 & 0.006 & 2.739 & NS \\
\hline Rotating shift group * Slower day shift group & 2.253 & NS & 3.614 & 0.03 & 3.335 & NS \\
\hline Rotating shift group * Faster day shift group & 2.253 & NS & 3.614 & NS & 3.335 & NS \\
\hline Slower day shift group * Faster day shift group & 2.253 & NS & 3.614 & NS & 3.335 & NS \\
\hline
\end{tabular}


Comparative analysis showed no statistically significant differences between fixed daytime workers and the different shift worker subgroups, suggesting that both fixed daytime workers and shift worker subgroups were stressed ( $F=2.739 ; p=0.352$ ) (Table 3 ).

We performed a correlation analysis between the demographic variables of the workers and the mean state and trait anxiety scores and the stress data to determine if any individual characteristics might be influencing our results. Analysis of the general sample workers showed no statistically significant relation. Nor were statistically significant correlations found between the demographic variables and the mean state-trait anxiety scores and stress data in an analysis of the different shift worker groups.

\section{Discussion}

The main findings of this study showed that shift workers had higher statetrait anxiety scores than those of fixed daytime workers. However, we found no differences in stress levels between the two groups. The higher situational anxiety (state anxiety) scores for the shift worker group corroborate previous findings of shift schedules increasing anxiety levels. This may be explained by the irregular sleep-wake cycle, desynchronized circadian rhythms or psychosocial problems caused by shift work (Akerstedt, Torsvall \& Gillberg, 1982; Akerstedt, Kecklund \& Knutsson, 1991; Monk, 2000; Ohayon, Lemoine, Arnaud-Briant \& Dreyfus, 2002). The irregularity of the sleep wake cycle and desynchronization are explained by two mechanisms: the homeostatic mechanism which, because of prolonged wakefulness and a reduced sleep phase, causes greater sleep propensity (Akerstedt \& Gillberg, 1981; Czeisler, Weitzman, Moore-Ede, Zimmerman \& Kronauer, 1980; Lavie, 1996); and the circadian mechanism, which over 24 hours distributes maximum and minimum moments of sleep propensity that coincide with some physiological rhythms such as body temperature (maximum temperature values coincide with minimum sleep propensity values and vice versa. On night shifts, homeostatic pressure may occur during wakefulness, with sleep initiating at the wrong circadian time, causing internal and external desynchronization. workers sleeping while their children and wives are awake (Borbély \& Ackerman, 2000). The alterations caused by shift work are interpreted as conflict by the workers, since they have to meet "antibiological" demands and work hours that are different from those of fixed daytime workers. They feel the need for sleep and suffer the health consequences caused by all these alterations. Taken together, these alterations may explain the higher situational anxiety levels found in shift workers. Corroborating this hypothesis, Suri, Sen, Singh, Kumar and Aggarwal (2007) found high rates of anxiety disorders in business process outsourcing shift workers when compared to day shift workers.

This disturbance or biopsychosocial conflict requires adjustment and adaptation and the need to develop strategies that overcome this crisis period by generating adequate responses (Caplan, 1980). During this adaptation period individuals develop what Lazarus and Folkman (1984) called confrontation strategies, defined as "constantly changing cognitive and behavioral efforts to cope with external or internal demands that are assessed as threatening or exceeding a person's resources" (p.240). These resources may regulate the emotional response to the problem or alter the problem that is causing the suffering. For this reason, we expected to find higher stress levels in the shift workers; however, the results showed no statistically significant differences between the two groups, and all those who exhibited stress (both shift and fixed daytime workers) were in the resistance phase. The resistance phase is the stress phase in which individuals automatically try to deal with their stressors to maintain their internal homeostasis (Lipp, 2000). These data suggest that work demands may be a predictor of high stress rather than the shift system itself, since in both groups (fixed daytime and shift workers), regardless of shift scheme, the work demands were numerous. As a result, both groups had high stress levels, were in the same stress phase and were trying to cope with these demands.

Rodrigues, Fischer and Brito (2001) found stress related to the offshore site and the workload in offshore workers submitted to several work schedules. Literature data using the same instrument (LSSI) corroborate our findings where, depending on the work requirements, workers develop stress and try to cope with the situation. 
Camelo and Angerami (2004), assessing stress in health professionals working day shifts, showed that the vast majority (83\%) displayed stress in the resistance phase. Bandeira et al. (2007), assessing stress in demented patient caregivers, concluded that they had stress in the resistance phase, but were already slipping into the quasi-exhaustion phase. Another explanation for the stress data is that the instrument we used to evaluate stress may not be sufficiently accurate to show the differences between the two groups.

Dispositional anxiety (trait anxiety) data showed that shift workers are also more anxious. Fischer (2004) and Monk (2000), Tamagawa, Lobb and Booth (2007), report that tolerance and susceptibility to shift work are influenced by various factors, among which are individual personality characteristics such as dispositional anxiety. A number of studies (Hemenover \& Dienstbier, 1998; Lazarus \& Folkman, 1984; Spielberger et al., 1979) found that high state anxiety or situational anxiety may be caused by personality structures that influence the way in which individuals perceive a stressful situation or event and how they react to it. For this reason, we suggest that the high situational anxiety levels in the shift worker groups may be caused by dispositional anxiety.

The state-trait anxiety and stress data of the three subgroups showed that they had high anxiety and stress levels and that the slower day shift group had higher dispositional anxiety scores than those of the other two groups (statistically significant). With regard to state-trait anxiety data, Saricaoglu et al. (2005), using IDATE, assessed anxiety in workers on a 12 hour day shift and in workers on a 12 hour night shift schedule and found similar data to those found in this study, that is, that all the workers had high anxiety and that no statistically significant differences existed between the two groups. Hemenover and Dienstbier (1998) showed that individuals with dispositional anxiety perform cognitive assessments according to their personality characteristics and to the importance and familiarity of the event, in addition to demonstrating their ability to use effective confrontation sources. The slower day shift workers are the only ones who work and sleep in a dangerous high seas environment, where they deal with petroleum extraction involving high pressures. Tomei et al. (2006) found high levels of dispositional anxiety associated with work organization in both shift workers and nonshift workers. A limitation to this study that may have influenced the results is the small number of slower day shift workers $(n=14)$.

Other variables may explain our results, such as lifestyle irregularity, which would be expected in workers on shift schedules because of circadians and homeostatics alterations that cause anxiety and stress. However previous results (Almondes \& Araújo, 2007) showed no statistically significant differences between the schedules, suggesting that demands and workload rather than shift work conditions are the main determinant of daily activity regularity. Furthermore, the type of work performed in each work schedule was not analyzed statistically, which could explain the anxiety and stress found in the work schedules studied here, despite our evaluating them indirectly through the work schedules, given that we characterized the function performed by the worker.

Another variable is the homeostatic alterations (alterations in sleep pattern) caused by the offshore or onshore site, which could increase the anxiety/stress levels. Moreover in the study conducted by Almondes and Araújo (2007) bad sleep quality was found at the two sites, but without statistically significant differences.

Taken together, our findings showed high anxiety levels (state and trait) in the shift worker groups and no difference between the fixed daytime schedules and the different shift schedules in terms of stress, demographic characteristics and work demands, suggesting that these high anxiety levels are a result of antibiological work schedules. Furthermore, it is important to point out that individual perception and interpretation are important in the association between shift work and the circadian, homeostatic and psychosocial alterations that provoke higher anxiety levels. For this reason, a cognitive and behavioral intervention, through learning strategies, may allow workers to change their understanding about the threats induced by all these alterations and thereby ease the consequences.

\section{Conclusion}

Shift work schedules cause more situational and dispositional anxiety. However, shift work and fixed daytime workers exhibited stress in the resistance phase, but without statistically significant differences. 


\section{References}

Almondes, K. M., \& Araújo, J. F. (2007). Qualidade de Sono e Qualidade deVidaem trabalhadores submetidos a diferentes esquemas de trabalho em uma empresa petroquímica. Tese de doutorado não-publicada, Universidade Federal do Rio Grande do Norte, Natal.

Akersdedt, T., Kecklund, G., \& Knutsson, A. (1991). Spectral analysis of sleep electroencephalography in rotating three-shift work. Scandinavian Journal Work Environment \& Health, 17 (5), 330-336.

Akerstedt, T., \& Gillberg, M. (1981). The circadian variation of experimentally displaced sleep. Sleep, 4 (2), 159-169.

Akerstedt, T., Torsvall, L., \& Gillberg, M. (1982) Sleepiness and shift work: field studies. Sleep, 5 (Suppl 2), S95-S106.

Bandeira, D. R., Pawlowski, J., Gonçalves, T. R., Hilgert, J. B., Bozzeti, M. C., \& Hugo, F. N. (2007). Psychological distress in Brazilian caregivers of relatives with dementia. Aging \& Mental Health, 11 (1), 14-19.

Barton, J., Aldridge, J., \& Smith, P. (1998). The emotional impact of shift work on the children of shift workers. Scandinavian Journal Work Environment Health, 24(Suppl 3), 146-150.

Borbély, A. A., \& Acherman, P. (2000). Sleep Homeostasis and Models of Sleep Regulation. In M. H. Kryger, T. Roth \& W. C. Dement (Eds.), Principles and practice of sleep medicine (pp.377-390). Philadelphia: W.B. Saunders.

Bourdouxhe, M., Quéinnec, Y., Granger, D., Baril, R. H., Guertin, S. C., \& Massicotte, P. R. (1999). Aging and shiftwork: the effects of 20 years of rotating 12-hours shifts among petroleum refinery operations. Experimental Aging Research, 25 (4), 323-339.

Camelo, S. H., \& Angerami, E. L. (2004). Symptoms of stress in workers from five family health centers. Revista Latino-Americana de Enfermagem, 12 (1), 14-21.

Caplan, G. (1980). Princípios de psiquiatria preventiva. Rio de Janeiro: Zahar Editores.

Choobineh, A., Rajaeefard, A., \& Neghab, M. (2006). Problems related to shiftwork for health care workers at Shiraz University of Medical Sciences. Eastern Mediterranean Health Journal, 12 (3/4), 340-346.

Costa, G. (2004). Multidimensional aspects related to shiftworkers' health and well-being. Revista Saúde Pública, 38 (Suppl 8),86-91.

Costa, G. (1996). The impact of shift and night work on health. Applied Ergonomics, 27 (1), 9-16.

Czeisler, C. A., Weitzman, E. D., Moore-Ede, M. C., Zimmerman, J. C., \& Kronauer, R. S. (1980). Human sleep: its duration and organization depends on its circadian phase. Science, 210 (4475), 1264-1267.

Fischer, F. M. (2004). Fatores individuais e condições de trabalho e de vida na tolerância ao trabalho em turnos. In F. M. Fischer, C. R. C. Moreno \& L. Rotenberg (Eds.), Trabalho em turnos e noturno na sociedade 24 horas (pp.65-76). São Paulo: Atheneu.
Fischer, F. M., Moreno, C. R. C., Borges, F. N. S., \& Louzada, F. M. (2000). Implementation of 12-hour shifts in a Brazilian petrochemical plant: impact on sleep and alertness. Chronobiology International, 17 (4), 521-537.

Harrington, J. M. (1994). Shift work and health: a critical review of the literature on working hours. Annals Academy of Medicine Singapore, 23, 699-705.

Hemenover, S. H., \& Dienstbier, R. A. (1998). Prediction of health patterns from general appraisal, attributions, coping, and trait anxiety. Motivation and Emotion, 22 (3), 231-253.

Kalia, M. (2002). Assessing the economic impact of stress: the modern day hidden epidemic. Metabolism, 51 (6 Suppl 1), 49-53.

Krivoschekov, S. G., Sobakin, A. K., \& Fomin A. N. (2003). Estimation of functional state and labour efficiency of shift workers in conditions of the Far North. Circumpolar Health, 63 (Suppl 2), 349-352.

Lazarus, R. S., \& Folkman, S. (1984). Stress, coping and adaptation. New York: Springer.

Lavie, P. (1996). The enchanted world of sleep. London: New Haven.

Lecrubier, Y. (2001). Prescribing patterns for depression and anxiety worldwide. Journal of Clinical Psychiatry, 62 (Suppl 13), 31-36.

Lipp, M. N. (2000). Inventário de sintomas de stress para adultos de Lipp (ISSL). São Paulo: Casa do Psicólogo.

Lowden, A., Kecklund, G., Axelsson, J., \& Akerstedt, T. (1998). Change from an 8-hour shift to a 12-hour shift, attitudes, sleep, sleepiness and performance. Scandinavian Journal Work Environment Health, 24 (Suppl 3), 69-75.

McVicar, A. (2003). Workplace stressing nursing: a literature review. Journal of Advanced Nursing, 44 (6), 633-642.

Monk, T. H. (1988). Coping with the stress of shiftwork. Work Stress, 2, 169-72.

Monk, T. H. (2000). Shift work. In M. H. Kryger, T. Roth \& W. C. Dement. Principles and practice of sleep medicine (pp.521- 525). Philadelphia: W. B. Saunders.

Monk, T. H., Frank, E., Potts, J. M. \& Kupfer, D. J. (2002). A simple way to measure daily lifestyle regularity. Journal Sleep Research, 11 (3),183-190.

Ohayon, M. M., Lemoine, P., Arnaud-Briant, V., \& Dreyfus, M. (2002). Prevalence and consequences of sleep disorders in a shift worker population. Journal of Psychosomatic Research, 53 (1), 577-583.

Olsson, K., Kandolin, I., \& Kauppinen-Toropainen, K. (1989). Stress and coping strategies of three-shit workers. Le Travail Humain, 53 (2), 175-188.

Piko, B. (1999). Work-related stress among nurses: a challenge for health care institutions. Journal of the Royal Society of Health, 119 (3), 156-162.

Portela, L. F., Rotenberg, L., \& Waissmann, W. (2004). Selfreported health and sleep complaints among nursing personnel working under $12 \mathrm{hrs}$ night and day shifts. Chronobiology International, 21 (6), 859-70. 
Reinberg, A., Andalauer, P., De Prins, J., Malbecq, W., Vieux, N., \& Bourdeleau, P. (1984). Desynchronization of the oral temperature rhythm and intollerance to shiftwork. Nature, 308 (5956), 272-274.

Rodrigues, V. F., Fischer, F. M., \& Brito, M. J. (2001). Shift Work at modern offshore drilling rig. Journal of Human Ergology, 30 (1-2), 167-172.

Rotenberg, L., Portela, L. F., Marcondes, W. B., Moreno, C., \& Nascimento, C. P. (2001). Gênero e trabalho noturno: sono, cotidiano e vivências de quem troca a noite pelo dia. Cadernos de Saúde Pública, 17 (3), 639-649.

Ruggiero, J. S. (2003). Correlates of fatigue in critical care nurses. Research in Nursing \& Health, 26 (6), 434-444.

Saricaoğlu, F., Akinci, S. B., Gözaçan, A., Güner, B., Rezaki, M., \& Aypar, U. (2005). The Effect of day and night shift working on the attention and anxiety levels of anesthesia residents. Turkish Journal of Psychiatry, 16 (2), 106-112.

Smith, L., \& Folkard, S. (1993). The perceptions and feelings of shiftworkers' partners. Ergonomics, 36 (1-3), 299-305.

Spielberger, C. D., Gorsuch, R. L., \& Lushene, R. E. (1979) Inventário de ansiedade traço-estado (Idate). Rio de Janeiro: CEPA.

Suri, J. C., Sen, M. K., Singh, P., Kumar, R., \& Aggarwal, P. (2007). Sleep patterns and their impact on lifestyle, anxiety and depression in BPO workers. Indian Journal of Sleep Medicine, 2 (2), 64-70.
Tamagawa, R., Lobb, B., \& Booth, R. (2007). Tolerance of shift work. Appllied Ergonomics, 38 (5), 635-642.

Tomei, G., Rosati, M. V., Ciarrocca, M., Capozzella, A., Pimpinella, B., Casale, T., C., \& Tomei, F. (2006). Anxiety, musculoskeletal and visual disorders in video display terminal workers. Minerva Medicine, 97 (6), 459-466.

Tucker, P., Barton, J., \& Folkard, S. (1996). Comparison of eight and 12 hour shifts: impacts on health, wellbeing and alertness during the shift. Occupational and Environmental Medicine, 53 (11), 767-772.

Twenge, J. M. (2000). The age of anxiety? Birth cohort change in anxiety and neurocitism, 1952-1993. Journal of Personality and Social Psychology, 79 (6),1007-1021.

Van Cauter, E., \& Spigel, K. (2000). Sleep as a mediator of the relationship between socieconomic status and health: a hypothesis. Annals of New York Academy of Sciences, 896, 254-263.

Williams, E., Magid, K., \& Steptoe, A. (2005). The impact of time of waking and concurrent subjective stress on the cortisol response to awakening. Psychoneuroendocrinology, 30 (2), 139-148.

Received on: 4/9/2007

Final version resubmitted on: 22/7/2008

Aproved on: 18/9/2008 